\title{
PENILAIAN KEMAMPUAN MEMBACA BAHASA ARAB ANAK KELAS RENDAH MADRASAH IBTIDAIYAH DI KABUPATEN PATI
}

\author{
M. Sofyan Alnashr \\ PGMI Fakultas Tarbiyah Institut Pesantren Mathali'ul Falah Pati \\ Email: sofyan@ipmafa.ac.id
}

\begin{abstract}
This study aims to assess the Arabic reading ability of early-grade children in the Madrasah Ibtidaiyah (MI) in Pati Regency. The research subjects were 36 children who were grade $3 \mathrm{MI}$ students from three madrasah namely MI Al Istiqomah, MI Thowalib, and MI Tarbiyatul Islamiyah. This research is in the form of qualitative descriptive research which begins with conducting an Arabic reading ability test then the scores obtained are analyzed with a qualitative approach. Each child is assessed by one assessor through structured interviews first followed by tests with 4 sub-tasks namely recognizing letters (sub-task 1 ), reading community letters (sub-task 2 ), reading words (sub-task 3 ), and reading sentences in Arabic (sub task 4). The results of the assessment show that $31 \%$ or 11 children get very good grades, this number is the same as children who get good grades, 11 children. While 19\% or 7 children are of sufficient value and $17 \%$ or 6 children are in the less category. There are 3\%, namely 1 child who still needs special assistance. From this study it can be concluded that early-grade MI children in Pati Regency have good abilities in reading Arabic script.
\end{abstract}

Keywords: assessment, reading Arabic, early-class.

\begin{abstract}
Abstrak
Penelitian ini bertujuan menilai kemampuan membaca Arab anak kelas rendah Madrasah Ibtidaiyah (MI) di Kabupaten Pati. Subjek penelitian berjumlah 36 anak yang merupakan anak didik MI kelas 3 dari tiga madrasah yaitu MIAl Istiqomah, MI Thowalib, dan MI Tarbiyatul Islamiyah. Penelitian ini
\end{abstract}


berupa penelitian diskriptif kualitatif yang diawali dengan melakukan tes kemampuan membaca Arab kemudian skor yang didapatkan dianalisis dengan pendekatan kualitatif. Setiap anak diasses oleh satu orang assesor melalui wawancara terstruktur terlebih dahulu dilanjutkan tes dengan 4 sub tugas yakni mengenal huruf (sub tugas 1), membaca huruf berharakat (sub tugas 2), membaca kata (sub tugas 3), dan membaca kalimat dalam bahasa Arab (sub tugas 4). Hasil penilaian menunjukkan data $31 \%$ atau 11 anak mendapatkan nilai sangat baik, jumlah ini sama dengan anak yang mendapat nilai baik yaitu 11 anak. Sementara 19\% atau 7 anak nilainya cukup dan $17 \%$ atau 6 anak masuk kategori kurang. Terdapat 3\% yakni 1 anak yang masih butuh pendampingan khusus. Dari penelitian ini dapat disimpulkan bahwa anak MI kelas rendah di Kabupaten Pati mempunyai kemampuan yang baik dalam hal membaca aksara Arab.

Kata kunci: assesmen, membaca Arab, kelas rendah.

\section{Pendahuluan}

Kemampuan membaca siswa di tingkat sekolah dasar/ madrasah ibtidaiyah (SD/MI) saat ini memiliki kecenderungan rendah. Hal ini terlihat dari penelitian yang dilakukan Progress in International Reading Literacy Study (PIRLS), yaitu studi internasional dalam bidang membaca pada anak-anak di seluruh dunia tentang kemampuan membaca anak. Tahun 2011 PIRLS melakukan studi tentang kemampuan membaca (Mullis, 2012) yang mengungkapkan bahwa hanya 5\% siswa Indonesia yang diteliti menunjukkan kemampuan membacanya sampai tingkat high dan advance, sementara lebih dari 30\% tingkatannya very low, hampir $40 \%$ hanya tingkat low dan bahkan hanya $25 \%$ saja siswa yang mencapai tingkat intermediate.

Penelitian sebelumnya yang juga dilakukan PIRLS tahun 2009 menunjukkan rata-rata anak Indonesia berada pada urutan keempat dari bawah dari 45 negara di dunia yang teliti. Dalam dua tahun ternyata kemampuaan membaca anak usia SD/MI tidak mengalami peningkatan dan cenderung stagnan. Rendahnya kemampuan membaca anak akan sangat berpengaruh terhadap pemahaman mereka dalam belajar. 
Ironisnya, kemampuan membaca anak Indonesia yang rendah ternyata berbanding lurus dengan minat baca masyarakat. Hasil survei dari studi Most Littered Nation In the World 2016 yang dilakukan pada tahun 2016 lalumenyatakan bahwa saat ini minat baca masyarakat Indonesia sangatlah rendah. Sebab minat baca di Indonesia menduduki peringkat 60 dari 61 negara. Rendahnya kemampuan dan minat baca -kebiasaan membaca- disinyalir menjadi faktor utama penyebab rendahnya budaya literasi. Padahal (Permatasari, 2015) salah satu upaya peningkatan mutu sumber daya manusia agar cepat menyesuaikan diri dengan perkembangan global yang meliputi berbagai aspek kehidupan manusia adalah dengan menumbuhkan masyarakat yang gemar membaca (reading society). Masyarakat akan cenderung lebih cepat mengalami, mengantisipasi dan menyesuaikan dengan berbagai perubahan dan kemajuan ketika individu-individu yang ada dalam masyarakat itu memiliki kemampuan dan budaya membaca yang tinggi (Krismanto, 2015). Namun kenyataannyamasyarakat belum mampu menyempatkan waktu secara sadar dan sengaja setiap harinya untuk membaca.

Kemampuan membaca dan minat baca yang rendah dari masyarakat menjadi masalah besar bagi bangsa ini terutama mereka yang bergelut di dunia pendidikan. Untuk itu, berbagai macam cara dilakukan supaya budaya membaca masyarakat Indonesia meningkat. Salah satunya melalui gerakan membaca sebelum pelajaran dimulai yang pernah digagas Anies Baswedan saat menjabat Menteri Pendidikan dan Kebudayaan. Hal ini dikuatkan lagi dengan Gerakan Literasi Sekolah yang diintegrasikan dalam kurikulum 2013 dengan tujuan meningkatkan minat baca anak sekolah. Meningkatkan gerakan literasi wajib dilakukan terutama di ruang pendidikan supaya melahirkan generasi literat dan berwawasan luas. Mustahil membangun peradaban bangsa yang maju tanpa dilandasi dengan budaya literasi yang tinggi dari masyarakatnya.

Dalam konteks pendidikan Islam, membaca merupakan perintah utama dan pertama yang diturunkan dalam bentuk wahyu dari Allah SWT kepada Rasulullah Muhammad

Elementary Vol. 7 No.1 Januari-Juni 2019 


\section{2| M. Sofyan Alnashr}

SAW. Shihab (Shihab, 2002) dalam kitab Tafsir aL-Misbah mengemukakan bahwa kata اقرأ (terambil dari kata قرأ qara'a) yang pada mulanya berarti menghimpun. Apabila anda merangkai huruf atau kata kemudian anda mengucapkan rangkaian tersebut maka anda telah menghimpunnya yakni membacanya. Dengan demikian, realisasi perintah tersebut tidak mengharuskan adanya suatu teks tertulis sebagai objek bacaan, tidak pula harus diucapkan sehingga terdengar oleh orang lain. Ini berarti bacalah dalam perintah tersebut yakni membaca teks dan konteks yaitu membaca Al-Quran dan Hadits serta fenomena alam dan sosial lainnya.

Membaca merupakan tindakan produktif yang melatih hampir semua kemampuan operasional yang dimiliki manusia meliputi pikiran (melalui otak untuk memahami), fisik (indera untuk melihat, memegang, dan melatih fokus) serta psikis (emosi, perasaan, dan mood). Membaca (Somadayo, 2011) adalah suatu kegiatan interaktif untuk memetik serta memahami arti yang terkandung di dalam bahan tulis. Membaca bagian dari komunikasi yakni memahami pesan dari penulis yang terkandung dalam bacaan. Membaca merupakan sebuah keterampilan, yakni kemampuan dan kecakapan dalam menyelesaikan sesuatu dengan efektif dan efisien, bermutu, dan sesuai. Seseorang yang dapat melakukan sesuatu dengan cepat tetapi salah tidak dapat dikatakan terampil.

Keterampilan membaca bukan sebuah insting atau kemampuan yang dimiliki secara alamiah, namun dibutuhkan latihan dan pembiasaan. Seperti halnya seorang anak yang belajar naik sepeda misalnya, ia harus terus berusaha dan melakukannya secara kontinu agar bisa terampil dalam bersepeda. Atau layaknya pilot yang dinilai profesionalitasnya dari banyaknya jam terbang yang pernah dilakukan. Maka keterampilan membaca anak juga perlu diasah secara terus menerus agar semakin terampil dan mahir dalam membaca.

Menurut Finonchiaro sebagaimana dikutip dalam (Tarigan, 2008), membaca adalah "bringing meaning to and getting meaning from printed or written material" (memetik serta 
memahami arti atau makna yang terkandung di dalam bahan tertulis). Atau dapat dikatakan membaca adalah menemukan makna dari simbol-simbol atau rangkaian kata yang ada dalam tulisan.Membaca teks berarti membaca ajaran agama Islam yang terkandung dalam Al-quran Hadits. Supaya memahami makna kandungan ayat dalam Al-Quran Hadits maka dasar utama seseorang ialah kemampuan Bahasa Arab yang memadai. Literasi Bahasa Arab menjadi hal mutlak yang harus dikuasai seseorang untuk memahami ajaran Islam dalam Al-Quran dan Hadits.

Kemampuan membaca dalam bahasa Arab dikenal dengan istilah maharah qira'ah yakni kemampuan berbahasa dalam memahami kandungan makna berdasarkan tulisan dengan baik dan benar. Untuk mencapai tahapan pemahaman dibutuhkan langkah-langkah yang sistematis dan bertahap. Target pembelajaran keterampilan membaca (maharah qiraah) ini adalah mampu membaca teks arab dengan fasih, mampu menerjemahkan dan mampu memahaminya dengan baik dan lancar.

Maharah qira'ah mengandung dua aspek (Muin, 2004) yaitu mengubah lambang tulis menjadi bunyi dan menangkap arti dari pada seluruh situasi yang dilambangkan dengan lambanglambang tulis dan bunyi tersebut. Inti kemahiran membaca terletak pada aspek yang kedua. Namun tidaklah berarti bahwa kemahiran dalam aspek yang pertama tidak penting sebab kemahiran dalam aspek yang pertama mendasari kemahiran yang kedua(Rahman, 2017). Kemahiran aspek pertama inilah yang diajarkan dalam masa permulaan (tingkat pendidikan dasar) dan mempunyai peran besar dalam menentukan kemahiran pada aspek yang kedua.

Jenjang pendidikan Islam formal di Madrasah Ibitidaiyah (MI) menjadi bagian penting dalam membentuk karakter anak yang mampu dan mau membaca dengan baik, termasuk membaca Arab. Kemampuan membaca Arab yang dibangun sejak masa kanak-kanak akan tumbuh menjadi karakter yang akan menetap hingga dewasa. Bahasa Arab menjadi 


\section{4| M. Sofyan Alnashr}

salah satu pembeda antara MI dengan SD selain beberapa mata pelajaran keagamaan lainnya. Bahasa Arab merupakan mata pelajaran bahasa yang diarahkan untuk mendorong, membimbing, mengembangkan, dan membina kemampuan serta menumbuhkan sikap positif terhasap Bahasa Arab, baik reseptif maupun produktif. Kemampuan reseptif yaitu kemampuan untuk memahami pembicaraan orang lain dan memahami bacaan. Kemampuan produktif yaitu kemampuan menggunakan bahasa sebagai alat komunikasi baik secara lisan maupun secara tertulis.

Kemampuan berbahasa Arab serta sikap positif terhadap bahasa Arab tersebut sangat penting dalam membantu memahami sumber ajaran Isalam yaitu al-Qur'an dan al- Hadis, serta kitab-kitab berbahasa Arab yang berkenaan dengan Islam bagi peserta didik. Untuk itu, Bahasa Arab di Madrasah dipersiapkan untuk pencapaian kompetensi dasar berbahasa, yang mencakup empat keterampilan berbahasa yang diajarkan secara integral, yaitu menyimak (mahaaratu al istimaa'), berbicara (mahaaratu al-kalaam), membaca (mahaaratul al Qiraa'ah), dan menulis (mahaaratu al kitaabah).

Di tengah rendahnya kemampuan dan minat membaca anak usia SD/MI di Indonesia yang rendah, lantas bagaimana dengan kemampuan membaca Bahasa Arab anak usia MI? Pertanyaan ini harus segera dijawab untuk mengetahui kemampuan membaca Arab anak usia MI karena memahami ajaran Islam dengan baik mustahil dilakukan tanpa memahami peninggalan utama dari Nabi Muhammad yaitu Al-Quran dan Hadits.

\section{Metode Penelitian}

Penelitian ini berupa penelitian diskriptif kualitatif, yakni penelitian yang berusaha mendiskripsikan gejala atau fenomena berdasarkan data kuantitatif yang didapatkan kemudian diolah dalam bentuk kualitatif supaya lebih mudah dipahami. Maksudnya ialah data awal berupa skor pengukuran hasil kemampuan membaca Arab anak MI kelas rendah kemudian diolah menjadi data kualitatif sesuai standar 
penilaian yang digunakan. Penelitian ini merupakan penelitian lapangan dengan pengambilan data berupa penilaian atau tes terhadap kemampuan membaca Arab anak MI kelas rendah. Data kuantitatif yang didapatkan kemudian dijadikan dasar dalam menentukan diskripsi secara kualitatif tentang seberapa baik kemampuan membaca Arab anak MI kelas rendah di Kabupaten Pati.

Objek dalam penelitian ini ialah anak MI kelas rendah di kabupaten Pati dengan mengambil sampel dari tiga MI di tiga kecamatan yang berbeda. Sementara subjek dalam penelitian ini yaitu siswa kelas rendah MI dan dipilihsiswa kelas 3 MI di kabupaten Pati dengan pertimbangan bahwa kelas 3 merupakan masa akhir kelas rendah yang berarti pula menjadi masa transisi dari kelas rendah menuju kelas atas. Di kelas 3 juga merupakan masa akhir membaca permulaan sekaligus masa awal membaca pemahaman.Kemudian dari tiga MI tersebut diambil sebanyak 12 siswa MI kelas 3 dengan sistem random sampling yang akan dinilai kemampuan membaca Bahasa Arabnya. Penelitian ini dilakukan di tiga MI di wilayah Kabupaten Pati, yaitu MI Tarbiyatul Islamiyah Winong Kecamatan Winong, MI Al Istiqomah Kedung Kecamatan Margoyoso, dan MI Thowalib Pesagen Kecamatan Gunung Wungkal.

Penelitian ini menggunakan beberapa instrumen, yaitu:

\section{a. Tes}

Tes dilakukan untuk mendapatkan data berupa hasil penilaian kemampuan membaca Bahasa Arab anak kelas 3 MI. Tes ini berguna untuk menilai kemampuan membaca Bahasa Arab terdiri dari empat macam tes membaca, yaitu:

1. Membaca huruf; siswa diminta menyebutkan huruf hijaiyah yang telah disediakan secara acak dengan durasi waktu 1 menit. Penilaiannya didasarkan pada ketepatan dan kecepatan membaca bahasa Arab anak.

2. Membaca suku kata/huruf berharakat; siswa diminta menyebutkan huruf hijaiyah yang berharakat dan disediakan secara acak dengan durasi waktu 1 menit. 
Penilaiannya didasarkan pada ketepatan dan kecepatan membaca bahasa Arab anak kelas 3.

3. Membaca kata;siswa diminta membaca kata dalam bahasa Arab (tidak mengeja) sebanyak 25 kata dengan durasi waktu 1 menit. Penilaiannya didasarkan pada ketepatan dan kecepatan membaca bahasa Arab anak.

4. Membaca kalimat pendek berupa potongan ayat dari Alquran atau Hadits sesuai dengan standar isi Bahasa Arab untuk MI. Selain potongan ayat juga terdapat kalimat sederhana dari percakapan sehari-hari. Semua materi diambil dari buku pelajaran Bahasa Arab MI sesuai standar isi yang tertuang dalam Peraturan Menteri Agama terbaru.

\section{b. Wawancara}

MetodeWawancara(interview) yaitu metode pengumpulan data dengan cara mengadakan wawancara dengan responden dan pihak-pihak lain yang terkait dengan masalah yang diteliti. Ciri utama dari interview (Sugiyono, 2009) adalah adanya kontak langsung dengan cara tatap muka antara pencari informasi (interviewer) dan sumber informasi (interviewee). Wawancarayang digunakan dalam penelitian ini adalah wawancara terstruktur untuk mendapatkan data diri anak, aktivitas membaca Arab di luar madrasah, sarana pendukung, dan dukungan keluarga. Data ini diambil dari wawancara langsung secara terstrukur sekaligus untuk mengetahui faktor apa saja yang mempengaruhi kemampuan membaca Bahasa Arab anak MI kelas rendah.

\section{c. Dokumentasi}

Dokumentasi yaitu metode pengumpulan data melalui dokumen, artifak, foto dan kumpulan data yang berbentuk tulisan lainnya. Dokumentasi digunakan sebagai penunjang data berupa objek penelitian, hasil belajar siswa, dan data lain yang penting untuk penelitian.

Langkah selanjutnya ialah melakukan analisis data yakni proses mencari dan menata data dari hasil observasi, wawancara dan dokumentasi secara sistematis untuk meningkatkan pemahaman peneliti tentang kasus yang diteliti 
dan menyajikannya sebagai temuan bagi yang lain (Muhadjir, 1996). Teknik analisis data dalam penelitian ini menggunakan analisis deskriptif untuk menganalisis hasil temuan.

Analisis deskriptif digunakan untuk melakukan perhitungan terhadap hasil penilaian dan dokumentasi, kemudian dari hasil perhitungan tersebut didekripsikan secara secara kualitatif dari data interview dan penilaian. Datadata yang didapatkan dalam penelitian tentang penilaian kemampuan membaca bahasa Arab anak kelas rendah MI ini kemudian diolah secara kualitatif untuk menunjukkan seberapa baik kemampuan membaca bahasa Arab anak kelas rendah MI di kabupaten Pati. Penilaian dilakukan dengan rentang (1) sangat baik, (2) baik, (3) cukup, (4) kurang, dan (5) butuh pendampingan khusus. Kemudian data tersebut disajikan dalam bentuk diskriptif kualitatif sehingga hasil penelitian dapat dipahami dengan mudah.

\section{Hasil dan Pembahasan}

Dari 36 peserta didik MI yang terpilih sebagai sample terdiri dari 17 anak laki-laki dan 19 anak lainnya perempuan. Jumlah laki-laki dan perempuan tidak sama karena terdapat satu madrasah (MI Al Istiqomah) yang jumlah siswanya 12 dengan 5 anak laki-laki sehingga jumlah sample laki-laki lebih sedikit. Sebelum melakukan assesmen tidak ada anak yang diberitahu akan ada penilaian. Jadi mereka menjalani penilaian sesuai kondisi alami masing-masing tanpa persiapan khusus.

Penilaian terhadap kemampuan membaca Arab anak MI kelas rendah di Kabupaten Pati dilakukan melalui 4 (empat) sub tugas yang harus dibaca. Sub-sub tugas tersebut yakni mengenal huruf (sub tugas 1), membaca huruf berharakat (sub tugas 2), membaca kata (sub tugas 3), dan membaca kalimat dalam bahasa Arab (sub tugas 4). Nilai dari tiap-tiap sub tugas kemudian dijumlah dan dibuat nilai rata-rata dari semua aspek tersebut. Nilai rata-rata itulah yang dijadikan nilai akhir dari penilaian kemampuan membaca Arab anak MI kelas rendah.

Dari hasil penelitian didapatkan jumlah anak dengan nilai sangat baik berjumlah 11 anak, jumlah ini sama dengan Elementary Vol. 7 No.1 Januari-Juni 2019 
anak dengan nilai baik. Total dari nilai anak yang baik dan sangat baik berjumlah 22 anak atau 61\%. Dengan data ini dapat disimpulkan bahwa anak MI kelas rendah di Kabupaten Pati mempunyai kemampuan membaca Arab yang baik. Lebih dari 60\% anak mampu membaca Arab dengan baik dan benar serta sesuai dengan tajwid (tartil).

Sementara anak dengan nilai cukup sebanyak 7 anak (19\%) dan 6 anak atau 17\% mendapat nilai kurang. Masih terdapat 1 anak (3\%) yang masuk kategori butuh pendampingan khusus dalam hal kemampuan membaca Arabnya. Sangat disayangkan karena masih terdapat anak dengan kemampuan kurang (6 anak) dan 1 anak kesulitan atau tidak memiliki kemampuan yang baik dalam membaca Arab.

Untuk memudahkan dalam membaca data di atas, maka hasil dari penilaian kemampuan membaca Arab anak MI kelas rendah di Kabupaten Pati ditampilkan dalam diagram berikut:

Kemampuan membaca Arab

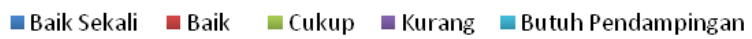

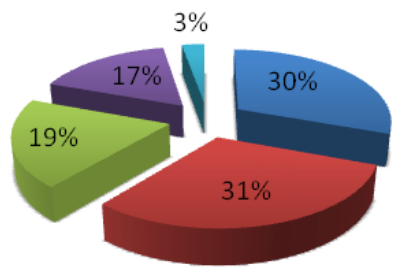

Assesmen lapangan memberikan data anak yang kurang mampu membaca dan butuh pendampingan khusus, yakni $17 \%$ yakni sebanyak 6 anak kemampuan membacanya kurang dan ada $3 \%$ atau 1 anak yang butuh pendampingan khusus dalam hal kemampuan membaca Arab. Memang tidak banyak anak yang mengalami kesulitan membaca Arab, namun data ini menjadi catatan bagi guru MI bahwa masih ada anak didiknya yang tidak mampu membaca Arab dengan baik.

Sebagai lembaga pendidikan Islam, tentu harapannya adalah tidak ada anak yang tidak bisa atau kesulitan membaca Arab. Berbeda dengan sekolah dasar umum yang tidak ada 
penekanan pada pemahaman agama Islam, anak didik madrasah harus bisa membaca Arab. Apabila ada anak didik MI yang belum bisa membaca Arab, maka harus didampingi dengan baik sehingga tidak ada lagi anak didik MI yang tidak bisa membaca Arab terutama untuk mengaji. Perlu diperhatikan bahwa kemampuan membaca Arab anak akan berpengaruh terhadap keterampilan berbahasa lainnya yakni menulis. Terdapat korelasi yang signifikan (Aquami, 2017)antara kemampuan membaca Alquran dengan keterampilan menulis huruf Arab. Semakin baik kemampuan membaca maka semakin baik pula kemampuan menulisnya.

Hasil penelitian tentang penilaian kemampuan membaca Arab anak MI kelas rendah di Kabupaten Pati memberikan gambaran bahwa mayoritas anak telah mampu membaca Arab dengan baik, namun masih ada anak yang kesulitan bahkan tidak mampu membaca aksara Arab. Penilaian kemampuan membaca Arab anak MI dilakukan dalam beberapa sub tugas (tes) sebagai berikut:

\section{Kemampuan Membaca Huruf Hijaiyah}

Huruf Arab disebut juga huruf hijaiyah yang berasal dari kata kerja hajjaa yang artinya mengeja atau menghitung huruf, membaca huruf demi huruf. Huruf hijaiyah berjumlah 28 huruf tunggal atau ada pula yang menyebut angka 30 huruf jika alif lam dan hamzah dianggap sebagai huruf yang mandiri. Cara menulis huruf hijaiyah ditulis dari kanan ke kiri, dan ini berbeda dengan penulisan huruf latin di mana cara penulisannya dari kiri ke kanan. Untuk memahami ajaran Islam dalam Alquran dan Hadits yang berbahasa Arab maka memahami huruf hijaiyah mutlak dibutuhkan.

Dalam penilaian yang dilakukan terhadap anak didik MI kelas rendah (kelas 3) di kabupaten pati, sebanyak 56\% anak telah mengenal huruf hiajiyah dengan sangat baik, dan $11 \%$ anak nilainya baik. Ini berarti $67 \%$ anak MI kelas rendah telah mampu membaca dan mengenal huruf hijaiyah dengan baik. Dengan pengenalan yang baik terhadap huruf hijaiyah maka tingkatan selanjutnya yakni membaca kata dan kalimat Arab Elementary Vol. 7 No.1 Januari-Juni 2019 
juga dapat dilakukan dengan baik pula. Kemampuan mengenal huruf hijaiyah menjadi modal dasar dan utama dalam membaca aksara Arab.

Mengenali dan memahami huruf hijaiyah menjadi modal utama anak dalam belajar Islam, tanpa pengenalan dan pemahaman yang matang maka anak akan kesulitan dalam belajar di madrasah. Distingsi madrasah dibandingkan sekolah umum ialah pemahaman dan materi pelajaran agamanya yang unggul, dan prasyarat utama untuk mencapai tujuan tersebut ialah dengan kemampuan membaca Arab yang baik. Dan kemampuan membaca Arab yang baik hanya dapat tercapai jika anak mengenal dan memahami simbol dasar dari aksara Arab yakni huruf hijaiyah.

Dari hasil penelitian, masih terdapat 11\% anak yang kemampuan mengenal huruf hijaiyahnya kurang serta masih terdapat 3\% atau 1 anak yang butuh pendampingan khusus dalam hal kemampuan mengenal huruf hijaiyah. Ini menjadi pekerjaan rumah yang harus diselesaikan oleh pengelola MI karena masih terdapat $14 \%$ atau sekitar 5 anak dengan kemampuan memahami huruf hijaiyah yang masih kurang. Madrasah sebagai lembaga pendidikan Islam harus mampu meningkatkan kemampuan mengenal huruf hijaiyah bagi anak didiknya sehingga kemampuan mengenal huruf anak didik MI minimal cukup dan tidak ada yang kurang apalagi butuh pendampingan khusus.

Pengenalan dan pembiasaan sejak dini akan mampu meningkatkan kemampuan anak dalam membaca Arab. Harapannya ialah ketika mereka lulus dari MI sudah mampu membaca Arab dengan baik dan benar. Tentu menjadi pukulan telak bagi sebuah madrasah apabila anak didiknya saat lulus dari MI tetapi belum bisa baca tulis Alquran. Maka identifikasi kemampuan mengenal huruf hijaiyah sejak kelas rendah akan membantu guru untuk menentukan siapa saja yang harus didampingi secara intensif. Sehingga pada saat mereka lulus sudah tidak ada anak MI yang kesulitan mengenal huruf hijaiyah. 


\section{Kemampuan Membaca Huruf Hijaiyah Berharakat}

Setelah mengenal huruf hijaiyah, sub tugas selanjutnya ialah kemampuan membaca huruf berharakat (suku kata). Harakat dalam huruf hijaiyah ialah fathah, kasrah, dan dhommah dan apabila ditulis dua berarti tanwin. Penggunaan tanda baca ini untuk memudahkan kaum muslimin dalam membaca Alquran karena pada awalnya tanda titik dan harakat belum ada ketika masa Rasulullah dan sahabat. Ketiadaan tanda dan harakat menyebabkan umat muslim yang hidup jauh setelah era Rasulullah kesulitan membacanya. Adanya tanda dan harakat jelas sangat membantu dalam belajar membaca Arab.

Penilaian terhadap kemampuan anak MI dalam membaca huruf hijaiyah yang berharakat menunjukkan hasil yang memuaskan. Sebagian besar anak MI kelas 3 telah mampu membaca huruf berharakat atau suku kata dalam bahasa Arab dengan sangat baik (75\%). Angka ini merupakan jumlah yang sangat besar yang artinya $3 / 4$ anak MI kelas rendah telah memiliki kemampuan membaca huruf hijaiyah yang berharakat dengan baik sekali.

Data tersebut juga menunjukkan bahwa anak lebih mudah belajar membaca dengan cara membaca suku kata langsung tanpa mengeja huruf demi huruf. Hal ini tidak bisa dilepaskan dari sistem pengajaran membaca Arab di Madin/TPQ yang menggunakan cara membaca langsung suku kata bukan melalui cara mengeja huruf demi huruf. Di satu sisi metode ini membuat anak lebih cepat dalam belajar membaca Arab, namun di sisi lain menjadi kurang memahami dan mengenali huruf hijaiyah dan syakalnya. Jika tujuannya ialah dapat dengan cepat membaca Arab maka metode seperti qira'ati dan yanbu'a yang saat ini populer bisa menjadi solusi.

Data anak yang memiliki kemampuan membaca huruf berharakatnya dengan sangat baik mencapai 75\%, sementara $19 \%$ anak memiliki nilai baik dan masing-masing 3\% yang nilainya kurang dan cukup. Hasil ini menjadi kabar baik karena hanya sedikit anak yang kemampuan membaca Arabnya dalam hal membaca huruf berharakat bernilai kurang. 
Prestasi membanggakan juga ada pada sub tugas ini di mana tidak ada anak yang butuh pendampingan (nilainya sangat jelek). Hal ini menunjukkan kemampuan anak dalam membaca huruf berharakat sudah sangat baik. Huruf hijaiyah yang dirangkai dengan harakat semakin mudah dipahami oleh anak, terlebih juga dalam keseharian mereka banyak yang belajar membaca Arab dengan cara langsung membaca huruf berharakat sehingga kemampuan membaca anak juga baik sekali.

Jelas terlihat bahwa pengajaran yang dilakukan di madin/ TPQdenganmenggunakan metodemembacasukukatalangsung berpengaruh sekali terhadap kemampuan membaca huruf berharakat anak MI kelas rendah di Kabupaten Pati. Prestasi ini harus terus ditingkatkan supaya kemampuan membaca Arab anak semakin baik. Membaca akan menambah wawasan dan pengetahuan anak, termasuk membaca Arab. Jika mereka sudah lancar membaca maka selanjutnya ialah meningkatkan kualitas pemahaman mereka atas teks yang dibaca.

\section{Kemampuan Membaca Kata Arab}

Sub tugas atau penilaian selanjutnya dilakukan untuk mengetahui kemampuan anak MI kelas rendah dalam membaca kata dalam bahasa Arab. Kata ialah rangkaian dari suku kata yang membentuk sebuah arti sehingga bisa dipahami oleh orang yang membaca. Dalam tahap ini seharusnya seseorang yang membaca juga sudah bisa memahami artti dari kata yang dibacanya. Akan tetapi karena subjek penelitian ialah anak MI kelas rendah maka penilaian terhadap pemahaman belum dilakukan. Penilaian dala sub tugas ini masih sama dengan sub tugas sebelumnya yaitu kemampuan anak membaca tulisan Arab dengan benar.

Hasil penelitian ialah anak kelas rendah MI di Kabupaten Pati dalam hal kemampuan membaca kata mayoritas nilainya sangat baik. Sebesar 58\% anak yang berarti lebih dari setengah anak MI kelas rendah telah mampu dengan baik membaca kata dalam bahasa Arab. Jumlah ini memang berkurang dari sub tugas sebelumnya (membaca suku kata) namun masih berada di

Elementary Vol. 7 No.1 Januari-Juni 2019 
atas $50 \%$ yang dapat disimpulkan bahwa kemampuan membaca kata anak MI masih sangat baik.

Sementara $14 \%$ anak mendapatkan nilai baik dalam sub tugas ini, sedangkan untuk nilai cukup dan kurang diperoleh masing-masing 11\%. Artinya masih banyak anak yang nilai membaca kata dalam bahasa Arab di bawah kategori baik. Memang hanya terdapat $6 \%$ atau kurang dari 2 anak yang butuh pendampingan khusus dalam sub tugas ini. Namun hasil ini juga mengindikasikan adanya anak yang belum bisa merangkai suku kata menjadi kata dalam bahasa Arab yang memiliki arti.

Madrasah dengan mata pelajaran agama yang unggul harus terus menekan angka ketidakmampuan anak dalam membaca Arab. Dalam rentang usia 7 - 9 tahun seharusnya anak sudah mampu membaca kata dalam bahasa Arab dengan baik. Nilai cukup masih bisa dimaklumi, akan tetapi jika masih ada nilai kurang dan butuh pendampingan dalam sub tugas ini maka madrasah harus selalu mendampingi anak didiknya secara intensif.

\section{Kemampuan membaca kalimat Arab}

Penilaian terakhir dalam penelitian ini ialah menilai kemampuan anak dalam membaca kalimat yang berbahasa Arab. Kalimat ini diambil dari potongan ayat Alquran, Hadits, atau dari kalimat sederhana sesuai materi ajar terutama Mata pelajaran bahasa Arab kelas 3. Jadi tingkat kesulitannya disesuaikan dengan perkembangan psikologis anak didik.

Hasil penelitian untuk sub tugas ini ialah 36\% anak telah mampu membaca kalimat Arab dengan sangat baik dan 11\% anak nilainya baik. Total hanya $47 \%$ atau kurang dari 17 anak yang telah mampu membaca kalimat Arab dengan baik dan lancar. Tingkat kesalahan membaca kalimat Arab anak didik MI ini sangat kecil dan ketepatan makharijul hurufnya juga baik.

Sementara untuk nilai kurang dan butuh pendampingan masing-masing sebesar $14 \%$ atau sekitar 5 anak sehingga totalnya ada 10 anak dengan kemampuan membaca Arab yang kurang bahkan butuh pendampingan khusus. Angka 10 anak 
tidak bisa membaca Arab merupakan jumlah yang banyak bagi madrasah.

Hal ini menunjukkan bahwa anak masih kesulitan merangkai kata demi kata menjadi sebuah kalimat. Jika melihat dari nilai sub tugas sebelumnya maka kemampuan membaca kalimat Arab menjadi sub tugas yang paling banyak nilai kurangnya. Padahal banyak anak dengan nilai baik dalam membaca huruf berharakat dan kata Arab.

Untuk madrasah yang notabene adalah sekolah Islam dengan jam belajar agama yang banyak, maka kemampuan membaca Arab anak MI dengan nilai baik kurang dari 50\% merupakan prestasi yang kuang bagus. Diperlukan langkah nyata untuk memperbaiki catatan ini supaya ketika anak memasuki kelas tinggi (kelas 4, 5, dan 6) mereka telah memiliki kemampuan membaca Arab yang baik sehingga saat lulus sudah lancar membaca Alquran.

Fokus penilaian baru pada tahap membaca belum sampai pada tingkat memahami bacaan. Jika dalam membaca saja masih banyak kekurangan maka anakakan banyak mengalami kesulitan dalam memahami bacaan. Membaca dan memahami merupakan satu kesatuan yang tidak bisa dipisahkan, namun dalam tahap belajar seperti kelas rendah MI membaca menjadi prioritas utama. Apabila sudah mampu membaca dengan baik tinggal dikembangkan untuk memahami bacaan.

Kemampuan membaca ibarat sebuah pintu gerbang pengetahuan kognitif karena dari membaca anak akan mendapatkan banyak pengetahuan penting yang berguna untuk kelangsungan perkembangan mereka. Dari proses membaca anak diharapkan mampu membangun pengetahuan mereka sendiri sesuai ajaran aliran kontruktivisme, salah satu filsafat pengetahuan yang menekankan bahwa pengetahuan kita adalah konstruksi (bentukan) kita sendirioleh struktur konsepsi sewaktu berinteraksi dengan lingkungannya(Suparno, 1997). Bentuk interaksi yang bisa menambah pengetahuan yaitu melalui kegiatan membaca. 
Dalam pembelajaran (Anderson, 1982), peserta didik harus diberi kesempatan untuk membangun pengetahuan secara aktif dalam kegiatan yang dilakukan peserta didik sehingga dapat menerima pengetahuan dari sumber kurikulum yang telah disusun. Sumber kurikulum yang banyak dan biasa dipakai di lingkup pendidikan formal negeni ini ialah buku paket atau buku bacaan dari penerbit atau pemerintah. Maka peningkatan literasi kemampuan membaca menulis sangat ditekankan oleh pemerintah melalui kurikulum 2013.

Pemerintah mencanangkan program Gerakan Literasi Sekolah (GLS) karena minat dan kemampuan membaca masyarakat yang sangat rendah. Dalam konteks madrasah, literasi tersebut juga berarti literasi bahasa Arab karena sumber materi dari mata pelajaran yang khas di madrasah berasal dari Alquran dan Hadits yang berbahasa Arab. Juga terdapat mata pelajaran Bahasa Arab, Nahwu, Shorof, dan muatan lokal lain yang banyak menggunakan bahasa Arab. Maka kemampuan membaca kalimat Arab harus terus diasah dan ditingkatkan oleh pendidik supaya anak didiknya tidak gagap mengikuti pembelajaran di madrasah.

Akan tetapi gerakan literasi di sekolah atau madrasah akan mengalami hambatan apabila tidak didukung dengan kebiasaan atau rutinitas membaca di rumah dan lingkungan masyarakat. Kegiatan seperti mengaji atau pendidikan di Madin menjadi hal penting dalam gerakan literasi ini. Tradisi mengaji dan belajar di Madin akan mampu meningkatkan keterampilan anak dalam maharah qira'ah sehingga anak tidak hanya akan pandai membaca namun juga dapat memahami makna kandungan dalam sebuah tulisan.

\section{Kesimpulan}

Dari hasil penelitian di lapangan, dapat ditarik kesimpulan bahwa kemampuan membaca Bahasa Arab anak kelas rendah MI di Kabupaten Pati sangat baik. Dari hasil penelitian didapatkan jumlah anak dengan nilai sangat baik berjumlah 11 anak, jumlah ini sama dengan anak dengan nilai baik. Total dari nilai anak yang baik dan sangat baik berjumlah 
22 anak atau $61 \%$. Sementara anak dengan nilai cukup sebanyak 7 anak (19\%) dan 6 anak atau 17\% mendapat nilai kurang. Masih terdapat 1 anak (3\%) yang masuk kategori butuh pendampingan khusus dalam hal kemampuan membaca Arabnya. Hasil ini menunjukkan prestasi yang cukup baik karena mayoritas anak mampu membaca Arab dengan baik. Aspek yang dinilai dalam penelitian ini ialah kemampuan mengenal huruf hijaiyah, membaca huruf berharakat, membaca kata dalam bahasa Arab, dan membaca kalimat atau potongan ayat Alquran.

\section{Penutup}

Demikian hasil penelitian ini kami sampaikan, semoga dapat memberikan manfaat bagi penulis, pembaca, serta masyarakat umum. Tentu dalam penulisan artikel ini masih banyak kekurangan dan kesalahannya, maka kami mohon maaf yang sebesar-besarnya. Tidak lupa ucapan terima kasih kepada Dirjen Diktis Kemenag RI sub bidang Penelitian dan Pengabdian Masyarkat yang berkenan memberikan hibah dan bimbingan untuk suksesnya penelitian ini. Wassalam.

\section{Daftar Pustaka}

Anderson, T. \&. (1982). Reader and Text Studying Strategies. (W. O. White, Ed.) New York: Academic Press.

Aquami. (2017). Korelasi antara Kemampuan Membaca AlQur'an dengan Keterampilan Menulis Huruf Arab pada Mata Pelajaran Al-Qur'an Hadits di Madrasah Ibtidaiyah Quraniah 8 Palembang. Jurnal Ilmiah PGMI, III (1), 77-88.

Krismanto, W. A. (2015). Meningkatkan Kemampuan Membaca Pemahaman Melalui Metode Survey, Question, Read, Recite, Review (Sq3r) Pada Siswa Kelas IV SD Negeri 46 Parepare. Jurnal Publikasi Pendidikan, V (3), 51.

Muhadjir, N. (1996). Metodologi Penelitian Kualitatif. Yogyakarta: Rake Sarasin. 
Muin, A. (2004). Analisis Kontrastif Bahasa Arab dan Bahasa Indonesia (Telaah terhadap Fonetik dan Morfologi). Jakarta: Pustaka Alhusna Baru.

Mullis, I. M. (2012). PIRLS 2011 International Report . Boston: TIMSS \& PIRLS International Study Center.

Permatasari, A. (2015). Membangun Kualitas Bangsa dengan Budaya Literasi. Prosiding Seminar Nasional Bulan Bahasa (p. 148). Bengkulu: UNIB.

Rahman, A. A. (2017). Keterampilan Membaca dan Teknik Pengembangannya dalam Pembelajaran Bahasa Arab. Jurnal Diwan, III (2), 159.

Shihab, M. (2002). Tafsir Al-Misbah (Vol. 15). Jakarta: Lentera Ilmu.

Somadayo, S. (2011). Strategi dan Tehnik Pembelajaran Membaca. Yogyakarta: Graha Ilmu.

Sugiyono. (2009). Memahami Penelitian Kualitatif. Bandung: Alfabeta.

Suparno. (1997). Filsafat Konstruktivisme dalam Pendidikan. Yogyakarta: Kanisius.

Tarigan, H. G. (2008). Membaca; Sebagai Suatu Keterampilan Berbahasa. Bandung: Angkasa. 
168| M. Sofyan Alnashr

Elementary Vol. 7 No.1 Januari-Juni 2019 